\title{
The Globalization-Deglobalization Policy Conundrum
}

\author{
Neil Dias Karunaratne \\ School of Economics, University of Queensland, Brisbane, Australia \\ Email: n.karunaratne@economics.uq.edu.au \\ Received January 30, 2012; revised February 10, 2012; accepted March 18, 2012
}

\begin{abstract}
The dynamic process of economic globalization and deglobalization has been occurring in "waves" over the past 250 years. Diffusion models reveal how globalization policies occupy the policy-centre stage when the global economy is booming and is cast on the back-burner when the global economy nose-dives into a slump. According to the diffusion models, when the global economy is booming the nodes that establish crucial linkages in the economy exceed the social optimum generating negative externalities thereby eroding social welfare in such a context policy intervention is justified to reduce the linkages that facilitate the spread of negative shocks or contagion that reduce the capacity for risksharing. The globalization-deglobalization policy conundrum also resurfaces in relation to trade flows, cross-border capital mobility, current account sustainability and technology diffusion. The latter has exacerbated the "digital divide" that has accompanied the revolutionary changes in information and communication technology (ICT) revolution by overcoming the "tyranny of distance". The recurrent global financial crises and speculative attacks on the currency peg have ignited the debate for reshaping the international financial architecture in order to reduce the vulnerability of the domestic economy to the disruptive effects of the global financial crises.
\end{abstract}

Keywords: Globalization; Deglobalization; Diffusion Process; Macroeconomic Economic Models; "Digital Divide"; Global Financial Crises; The Global Financial Architecture

\section{Introduction}

The process of economic globalization that has occurred in "waves" over the past 250 year reveals the stylised fact that policies that promote globalization occupy the policy centre stage when the global economy is booming and gets cast on to the backburner when the global economy nose dives into a slump. The central aim of this paper is to explain this policy conundrum of globalization and deglobalization as the global economy flips from a boom to a slump. Conventional models shed light on the causes that underpin the policy conundrum and provide a rationale for the case for reshaping the global financial architecture aimed at reducing the vulnerability of the global economy to recurrent crises.

The rest of the paper is structured as follows: Section 2 presents a critical review of the on-going heated debate between the proponents of globalization and deglobalization. Here, five of the major "waves" of globalization and deglobalization have been identified. Section 3 reviews insights from models of pure theory of international trade to demonstrate that free trade is best during episodes of global prosperity and protectionist policies comes up trumps during episodes of global downturns. Section 4 reviews the controversy about current account sustainability and the misguided case for policy targeting the reduction of the current account deficit when the economy enjoyed fiscal balance. Section 5 examines the issue of convergence in the context of the neoclassical and endogenous growth models. Section 6 uses the gravity model to shed light on overcoming the "tyranny of distance" and the exacerbation of the "digital divide" due revolutionary changes in Information and Communication Technology (ITC) revolution. Section 7 deals with the phenomena of currency crises and exchange rate misalignment. Section 8 examines the case for reshaping the International Economic Architecture. Section concludes the paper

\section{The Globalization Deglobalization Conundrum}

The paper analyses mainly the dynamic processes of economic globalization whilst deliberately side-tracking the analysis of non-economic issues of globalization linked to cultural homogenization, climate change, human rights abuse and the war against terrorism based on the author's own perceptions by drawing on other studies on the subject by O'Rourke and Williamson [1] and Dollar [2], five main waves of globalization and deglobalization have been identified in this paper (see Table 1).

A major bone of contention between the globalizers 
Table 1. Waves of globalization \& deglobalization.

\begin{tabular}{ccccc}
\hline Wave type & Duration & Propeller & Economy & Architecture (IFA) \\
\hline Globalization I & $1870-1914$ & Colonization & Boom & Gold Standard \\
Deglobalization I & $1914-1930$ & Protectionism & Slump & Inter-War \\
Deglobalization II & $1939-1946$ & Inter-War & Slump & Inter-War \\
Globalization II & $1946-1973$ & Free Trade & Boom & Bretton Woods \\
Globalization III & $1980-2009$ & Capital mobility & Slump & Generalized Float \\
\hline
\end{tabular}

Sources: O'Rourke et al. [1] and Dollar [2].

and deglobalizers relate to the issue of reduction of poverty and income inequality. The deglobalizers have alleged that despite waves of globalization more than 1 billion people live below the poverty line of less than 1 US $\$$ per day. In this morass of poverty more than 30,000 children were perishing daily due to malnutrition and over 72 million children of whom $57 \%$ were girls had no primary education and entered the new millennium as illiterates. The above poverty facts and stats constitute a strong indictment of past globalization as it has failed to work to improve the welfare of the poor in developing countries as observed by Shah [3] (Table 2).

Nonetheless, a more incisive analysis of the poverty and income inequality data based on the percentage of population living below the poverty line of US \$1 per day over two decades 1960-1980 analysed according to the major regions of the global economy reveal that the percentage of population living below the poverty line has fallen significantly in the emerging market economies of East Asia, South Asia and the oil producing nations of the Middle East while only Sub-Saharan Africa has been bypassed by the globalization process and showed no significant reduction in poverty. Overall, the percentage of persons living below the poverty line has fallen by nearly $10 \%$ and for the first time the growing trend of income inequality has reversed mainly due to rapid growth and poverty alleviation programs that have implemented by the mega Asian economies of China and India as shown by Salvatore [4] (Table 3).

During this last wave or Wave III of globalization, the economic centre of gravity that was located in the US-North Europe region started to shift to the East Asia-Pacific region ushering in new era of globalization centred on the emergent economies of East Asia and the Pacific. World development indicators revealed that in the East-Asia Pacific region per capita GDP growth had increased at a whopping rate of nearly $9 \%$ per year, productivity had more than trebled, carbon dioxide emissions nearly doubled indicating that region was turning into the leading engine of global economic growth whilst at the same time improving the quality of life as shown by reduction of infant mortality by nearly half, increas- ing life-expectancy from 67 to 71 years and increasing the ratio of enrolment in tertiary education to more than 20\% (Table 4).

In this paper, we use the modelling of diffusion process to explain the working of the paradox high started with the adverse shock of the US subprime mortgage meltdown, which spread apidly erupting as a full-blown financial crisis. This ended the longest wave of prosperity, Wave III of Globalization, also known as the "Great Moderation" and engulfed the global economy in a full blown financial crisis in August 2007 and commenced Wave III of deglobalization policies during the worst slump that occurred since the Great Depression of the 1930s. The US subprime mortgage meltdown, which had its origin in the US housing market, had spread rapidly worldwide and posed a systemic threat of a collapse of the global financial architecture or system. Based on insights from diffusion models during a global lump he interconnection between crucial nodes exceed what is desired from the social optimum requiring disconnecting nodes or deglobalization in order to regain economic stability. The adverse shock of the US subprime mortgage meltdown is transmitted around the network in two ways. First, the original shock may be sub-divided among the nodes resulting in risk-sharing. The analysis of the US subprime mortgage meltdown reveals that the root cause of the current global financial crisis can be traced to the financial innovation of securitization which repackaged prime and subprime mortgages and increase the marketability of these repackaged assets by creating mortgage backed securities (MBS). The shift from "originate and hold" model to the "originate and distribute" model increased the marketability of securitized assets but at the same time by increasing counterparty risk created: a "credit crunch" and a "liquidity crisis" which rendered Wall Street institutions insolvent... However, the Wall Street financial institutions were deemed to be either "too big to fail" or "too interconnected to fail" that justified a tax-payer funded bailout creating a serious moral hazard problems. The recurrent global financial crises has led to calls to reshaping the international financial architecture (IFA). 
Table 2. Poverty facts and stats.

\begin{tabular}{ll}
\hline & \multicolumn{1}{c}{ Indicator of Developing Country Poverty } \\
\hline 1. & $50 \%$ of the world population (3 billion) live on less than 2 dollars a day. \\
2. & $80 \%$ of the world' population live in countries widening income inequality. \\
3. & $20 \%$ of the world's rich enjoy $75 \%$ of the global wealth while $40 \%$ of the world's poorest account only $5 \%$ of the world's wealth. \\
4. & 30,000 children die every day due to poverty (UNICEF). \\
5. & $28 \%$ of children in DCs are underweight or stunted. \\
6. & 72 million children of primary school age do not attend school, $57 \%$ are girls. \\
7. & Over 1 billion people entered the new millennium illiterate.
\end{tabular}

Source: Shah [3].

Table 3. Number \& percentage living below the poverty line (1960-2000) during Globalization Wave II \& III.

\begin{tabular}{cccc}
\hline Region & $1960(\%)$ & 1980 & 2000 \\
\hline East Asia & $729(77.5)$ & $955(67.2)$ & $114(6.0)$ \\
South Asia & $209(37.2)$ & $310(34.4)$ & $105(7.8)$ \\
Sub-Saharan Africa & $118(53.2)$ & $10(4.3)$ & $362(54.8)$ \\
Mid-East \& N. Africa & $32(24.3)$ & $13(3.6)$ & $29(7.2)$ \\
Latin America & $35(16.0)$ & $7(1.7)$ & $27(5.2)$ \\
Eastern Europe & $29(9.2)$ & $1479(43.5)$ & $647(13.1)$ \\
Developing World & $1131(52.5)$ &
\end{tabular}

Source: Salvatore [4]. Notes: (Poverty line: Living on less than US $\$ 1.00$ per day measured in 1985 PPP $=$ Living on less than US $\$ 1.50$ per day measured in 1993 PPP).

Table 4. World development indicators (1990-2006).

\begin{tabular}{ccccccc}
\hline Region & $\% \Delta$ PCGDP & $\% \Delta$ PROD & $\% \Delta \mathrm{CO}_{2}$ & Infant Mortality & Life Exp. & Tertiary ed. Enrol. Ratio \\
\hline East-Asia Pacific & 8.6 & 315 & 198 & 56 to 29 & 67 to 71 & 20 \\
Sub-Sahara Africa & 3.0 & 12 & 12 & 123 to 83 & 50 to 50 & 5 \\
High Income & 2.2 & 135 & 122 & 12 to 7 & 76 to 79 & 67 \\
World & 2.6 & 141 & 128 & 92 to 73 & 65 to 68 & 24 \\
\hline
\end{tabular}

Source: Klein [7].

\section{Models of Pure Theory of Trade \& Protectionism}

A major force of driving economic globalization is trade liberalisation or the removal of tariff and non-tariff barriers on the trade in goods and services. Pure theory of international trade as exposited in the Riparian model, see Appleyard et al. [5] demonstrates that specialisation in the production of goods based on the principle of comparative advantage maximizes national and global welfare or is first best. However, when factor endowments are taken into account the Heckscher-Ohilin model demonstrates that free trade results in income distribution effects or winners and losers. If the winners from trade can potentially compensate losers and still be better off the free trade is still first best. Although the rhetoric of free trade is strongly supported in multilateral trade negotiations as discussed by Pattnaik [6], under the auspices of the World Trade Organisation by the champions of free trade in reality these very champions cave into demands of special interest groups and perpetuate, for example, farm subsidies undermining both national and global welfare. The stalling of the $9^{\text {th }}$ round of MTN or the Doha round bears testimony to the fact that the political economy of protection overrides the benefits of free trade particularly, during periods of global economic 
slow-down. The benefits of free trade clearly demonstrate that the Asian miracle has delivered high growth rates to a group of High Performance Asian Economies (HPAEs) that implemented export oriented industrial strategies in contrast to several developing countries that pursued inward looking import substituting industrialization (ISI) strategies. Besides, new trade theories that take into account the effects of economies of scale and monopolistic competition show that trade in similar but differentiated products between countries or intraindustry trade as opposed to inter-industry or Heckscher-Ohlin trade in dissimilar products do not take into account perverse income distributional effects.

The world's centre of economic gravity has shifted from the North America and Pacific region. Data on overall economic activity, national accounts, demographics, sexual specifics, health life expectancy, energy, and output show that growth centres have shifted from North America and Europe to Asia and America according to Klein [7]. Empirical studies show that this reduction led to the reduction of the tyranny distance for countries like Australia. The reduction of the distance from the North America-Europe to the Asian Pacific region has increased the potential for trade with the fast growing emerging market economies in China and India.

The last wave or Wave III, of economic globalization dubbed the "Great Moderation" delivered unprecedented prosperity due to the financial innovations nurtured by the spread of free market capitalism. However, unregulated free market capitalism also sowed its own seeds of destruction and resulted in the Wave III of economic globalization that imploded in the US subprime mortgage meltdown, which exploded as a full-blown global financial crisis in August 2007 engulfing the world in the worst global recession since the Great Depression of the 1930s.

The insights garnered from the diffusion models reveal that when the global economy is booming the interdependencies of the real and financial assets increase enhancing social welfare. However, when the global economy plunges into a slump the private incentives exceed the social welfare optimum eroding the capacity of financial networks to reduce risk-sharing due to the crisis contagion that arises from the increase in volatility. Risk-sharing is defined as the subdivision of the original shock amongst the nodes of a network and crisis contagion is defined as the spread (multiplication) of the shock among nodes of network (convergence). Diffusion processes suggest that during a global slump policy intervention should aim at disconnecting the economy at crucial nodes to reduce private incentives that exceed the social optimum. Besides, policy intervention should be directed at revamping institutions and not rescuing bad managers increased inefficiency by causing the divergence of pri- vate from the social welfare optimum.

The subprime mortgage meltdown which unravelled as the worst global recession in August 2007 since the Great Depression of the 1930 ended the Great Moderation or a long-boom in the global economy plunging the global economy in a slump. As predicted by the diffusion processes model the global slump increase the interdependencies between the financial and real sectors. The subprime mortgage meltdown affected securitization or the pooling of prime and subprime mortgages and obtaining for these asset backed securities high rating from hedge funds thereby increasing their marketability world-wide. The process of pooling subprime mortgages with prime mortgages which radically changed banking lending from the "Originator to Hold" model to "Originator to Distribute" model enabling banks to obtain high ratings from hedge funds for the asset backed securities and increase their marketability world-wide. During economic booms when house prices were rising subprime mortgagees were able to refinance their loans and meet their repayments. However, the US housing price bubble burst and housing prices plummeted the subprime mortgagees were unable to meet the high interest payments and therefore they sold their houses increasing the supply house at a time when demand was low. This caused a further fall in house prices and forced subprime mortgagees to default on their repayments and banks to foreclose on them. The negative feedbacks arising from the US subprime mortgage meltdown was transmitted globally because many foreign banks, hedge funds, superannuation funds and other investors had bought asset backed securities which had mispriced risks in their search for higher yields.

The US subprime mortgage meltdown created a "credit crunch" which spawned a "liquidity crisis" and lending agencies were unable to obtain loans from the interbank market to meet the demand for credit for maturities of more than month because of the widening gap in interbank spreads due to increase in counterparty risk. This drove Wall Street financial institutions to the throes of bankruptcy and insolvency. However these Wall Street financial institutions were deemed to be "too big to fail" or "too interconnected to fail".

The insights garnered from the diffusion models reveal that when the global economy is booming the interdependencies of the real and financial assets increase enhancing social welfare. However, when the global economy plunges into a slump the private incentives exceed the social welfare optimum eroding the capacity of financial networks to reduce risk-sharing due to the crisis contagion that arises from the increase in volatility. Risk-sharing is defined as the subdivision of the original shock amongst the nodes of a network and crisis contagion is defined as the spread (multiplication) of the shock among nodes of 
network (convergence). Diffusion processes suggest that during a global slump policy intervention should aim at disconnecting the economy at crucial nodes to reduce private incentives that exceed the social optimum. Besides, policy intervention should be directed at revamping institutions and not rescuing bad managers increased inefficiency by causing the divergence of private from the social welfare optimum as analysed by Gallegati et al. [8].

The subprime mortgage meltdown which unravelled as the worst global recession in August 2007 since the Great Depression of the 1930 ended the "Great Moderation" or the long-boom in the global economy plunging the global economy in a slump. As predicted by the diffusion processes model the global slump increase the interdependencies between the financial and real sectors. The subprime mortgage meltdown affected securitization or the pooling of prime and subprime mortgages and obtaining for these asset backed securities high rating from hedge funds thereby increasing their marketability world-wide. The process of pooling subprime mortgages with prime mortgages which radically changed banking lending from the "Originator to Hold" mode to "Originator to Distribute" mode enabled banks to obtain high ratings from hedge funds for the asset backed securities and market them world-wide. During economic booms when house prices were rising subprime mortgagees were able to refinance their loans and meet their repayments. However, the US housing price bubble burst and housing prices plummeted the subprime mortgagees were unable to meet the high interest payments and therefore they sold their houses increasing the supply house at a time when demand was low. This caused a further fall in house prices and forced subprime mortgagees to default on their repayments and banks to foreclose on them. The negative feedbacks arising from the US subprime mortgage meltdown was transmitted globally because many foreign banks, hedge funds, superannuation funds and other investors had bought asset backed securities which had mispriced risks in their search for higher yields.

The US subprime mortgage meltdown created a "credit crunch" and "liquidity crisis" because the widening spreads of counter-party risks. This drove Wall Street financial institutions to the throes of bankruptcy and insolvency. However these Wall Street financial institutions were deemed to be "too big to fail" or "too interconnected to fail".

In this paper we have identified five waves of globalization and deglobalization of different duration, each propelled by its own major engine of economic force (see Table 1). The issue of globalization has been the subject of heated controversy as pro-globalizers have highlighted those emerging market economies that embraced the globalization policies have experienced miracle growth rates and reduced poverty and income inequality and converged to the living standards of the industrial countries. Proponents of deglobalization or anti-globalization have voiced their serious dissent on the rosy view of globalization and they highlight the fact that more than 1 billion people live below the poverty line of less than one US \$ a day. They argue that globalization has made the rich in the rich countries richer all at the expense of the poor in poor countries and increased the vulnerability of the global economy to catastrophic crises that strike the global economy with increasing frequency and virulence and motivating the deglobalizers to demand a radical reshaping of the global financial architecture to make globalization deliver for the poor and make the world a better place to live in industrial economies richer and widen the economic This paradoxical policy switch from globalization to deglobalization as the global economy flips from a boom to a slump is the central focus of analysis of this paper. The global economy experienced the longest wave of prosperity during the post War period in Wave II and Wave III which has ended with the sudden eruption of a global financial crisis in August 2007, engulfing the global economy in the worst recession since the Great Depression of the 1930s (see Table 1).

Wave III of globalization, also referred to as the "Great Moderation" can be explained by the financial innovations known as securitization or pooling of subprime and prime mortgages into asset backed securities and marketing them globally after securing high ratings from hedge funds. The change in the financial market structure from the "origin to hold" banking to "origin to distribute" banking occurred because repackaged or pooled asset backed securities obtained high ratings from hedge funds and were market worldwide. When the global economy was booming subprime mortgagees were able to refinance their subprime mortgages as long as house prices kept on rising. However, when the US housing price bubble burst and interest rates rose subprime mortgages unable to make repayments on their mortgages sold their properties increasing the supply of houses and causing a further fall in house prices. The fall in house prices made it problematic for subprime mortgagees to refinance their mortgages on more favourable terms causing them to default on repayments and making banks in foreclosing on them. These negative feedbacks caused by the subprime mortgage meltdown increased the counterparty risks and made increased the interbank interest rate differential making it difficult for banks to obtain credit leading to a "credit crunch" and "liquidity crisis" driving Wall Street financial institutions into bankruptcy and virtual collapse. However, these Wall Street financial institutions were deemed to be "too big" or "too connected" to allow them to fail and therefore they were 
bailed out at tax-payers' expense creating a moral hazard problem. The central issue investigated in this paper is how an adverse domestic shock like the subprime mortgage meltdown spread rapidly across the globe plunging a global economy that was booming and promoting policies of globalization into a slump where deglobalization policies surfaces to the policy centre stage. This paradoxical shift from promoting globalization to policies that promote deglobalization as the global economy plunges from booms to slumps is manifest in the conventional macroeconomic models that explain trade, crossborder capital flows, technology transfer and labour flows.

In modelling the diffusion process we define a negative shocks that can be subdivided among nodes of a net work is defined as risk-sharing ( mean reversion), while a negative shocks that can be spread among nodes of a network (multiplied) is defined as contagion (convergence). The examination of the subprime mortgage meltdown through the lens of a diffusion process models reveals that financial innovations like securitization or the pooling of subprime and prime mortgages that was made possible by off-balance-sheet activities under the "originate and distribute" banking increased the marketability of the securitized assets by obtaining high ratings for them from hedge-funds that mis-priced the risk of asset backed subprime mortgage assets or securitized assets. As long as the US housing prices soared the subprime mortgagees could refinance their mortgages on favourable terms. However, when the US housing price bubble burst the subprime mortgages were unable to meet their interest payment obligations and they were forced to sell their properties. This increased the supply of houses at a time when demand had collapsed causing house prices to fall further and interest rates to rise resulting in widespread default on repayment and foreclosures by banks and other nonbank lending agencies. The turbulence in the housing market adverse repercussions in the interbank market increasing counterparty risks and impeding central banks role to function as 'lender of last resort' as banks and lending agencies could not obtain credit to finance loans with maturity over one month creating a "credit crisis" and then a "liquidity crisis" according to Mizen [9]. The liquidity crisis drove the Wall Street financial institutions to insolvency. However, these Wall Street institutions were deemed to be "too big" or "too interconnected' to allow them to fail. Therefore, they were bailed-out at the taxpayers' expense sparking off a heated debate on moral hazard problems that were created by tax-payer funded bailouts o Wall Street financial institutions.

\section{External Imbalance and Current Account Sustainability}

A dominant paradigm that provided policy guidelines to achieve internal and external balance in a small open economy was the Mundell-Fleming model. This model under a fixed exchange rate regime directed that policies should aim at reducing high current account deficits that exceeded $5 \%$ as a ratio of GDP flashed a red light that the country was living beyond its means as warned by Milesi-Ferrrati and Razin [10]. However, the rationale for targeting the reduction of the current account deficit became obsolete when the exchange rate was floated and capital controls were dismantled as the current account deficit was the residual outcome of optimizing decisions of rational agents rendering policy actions to reduce current account deficits was misplaced as hypothesised by Pitchford [11] and Corden [12]. The polemics relating to the sustainability of high current account deficits and the fetish exhibited by policymakers in Australia to an obsolete open economy model has been revisited critically reviewing the implications of following policies based on the obsolete Mundell-Fleming model in contrast to policies based on intertemporal optimization under a flexible exchange rate regime as analysed by Karunaratne [13]. The evolution of monetary policy as the exchange rate was floated in Australian in 1983Q4, and capital controls were dismantled, and this required that fixed exchange rate anchor be abandoned and that policymakers combine the options of a floating exchange rate regime with monetary policy autonomy instead of running into the "impossible trinity" or the open economy "trilemma" according to Obstfeld et al. [14]. The redesigning of the Australian monetary policy by shifting from the Mundell-Fleming model to the intertemporal optimization approach in Australia was reinforced with Australia joining the leaguer of inflation targeters with the add-on the institutional of Central Bank Independence. These institutional innovations facilitated the promoting of globalization of the Australian economy without creating an inflation bias and underming policy credibility by succumbing into time-inconsistent policies. Therefore, for nearly two decades advanced countries like Australia integrated with the global economy reporting low inflation and high growth rates. However, as we foreshadowed in Section 2 the eruption of the global financial crisis due to the subprime mortgage meltdown completely reversed the trends toward globalisation by plunging the global economy into an unprecedented recession.

\section{Convergence-Neoclassical and Endogenous Growth Models}

Promotion of economic growth to reduce poverty and income inequality has been one of the central objectives of economic development and growth as addressed in the neoclassical growth models of Solow [15] and Swan [16], 
the Solow model also uses a growth accounting equation to analyse the major drivers of economic growth. Therefore, policies aimed at promoting economic growth should focus on providing incentives to nurture to technological progress or innovation, also referred to as "inspiration". Empirical studies of growth in the Asian tiger economies reveal that much of the growth was due to increase in physical inputs (capital and labour) or "perspiration" rather than technological progress. But since physical factor inputs are subject to the law of diminishing marginal productivity of physical capital and was predicted that high growth rates of the Asian Tiger economies will would peter out producing an economic crisis as demonstrated by Kurgan [17] and Young [18]. The Solow-Swan model also provide insights on the policies that should be pursued to reduce current consumption and in order to increase the consumption of future generations giving what is known as a Golden Rule policy prescription which requires "that you should do unto others what you would have them do unto you." according to Phelps [19]. These are conflicting perspectives on the interactions of population growth and the rate of capital accumulation, which according to the dismal Malthusian model on population growth will drive an economy to an eternal cycle of poverty and misery but according to the more optimistic Kremerian model population growth emerges as the motor of technological innovation and new ideas that will deliver everlasting prosperity.

The Solow-Swan model predicts absolute convergence or low income developing countries that grow faster will eventually "catching-up" high capita income levels of rich countries. However, empirical studies based on the pooling of ACs and DCs fail to support the prediction of absolute convergence and instead indicate conditional convergence where low income DCs converge to their own steady state per capita income levels, while rich ACs converge their own high steady per incomes resulting in the formation of poor country and rich country "convergence clubs" according to Barro et al. [20]. Therefore, based on the evidence of conditional convergence deglobalizers have argued that globalization has contributed to the divergence of per capita incomes of ACs and DCs rather than their convergence.

The Solow-Swan model and its growth accounting empirics indicate that benefits of growth are mixed mainly because it assumes that technological progress is exogenous. However, endogenous growth models, which indigenise technological progress indicate that economic growth can deliver everlasting growth. For example the simple AK model assumes a broader definition of capital (K). Here capital includes not only physical capital that is subject to the law of diminishing marginal returns, but human capital that gives increasing returns under the assumption of constant returns to scale therefore policies that promote the development of human capital and skill formation according to the $\mathrm{AK}$ model predicts that growth could be perpetual because of the absence of the deleterious effects of exogenous technological progress. ${ }^{1}$

Trade between ACs and DCs based on the principle of comparative advantage can occur through different modes. First, trade between nations could be interindustry trade as explained by the Heckscher-Ohlin model. Second, trade could be inertemporal trade or exchange of goods and services for future goods and services. Third, assets could be traded for other assets in order to diversify asset portfolios and maximise expected risk adjusted according to the Markowitz portfolio selection model [21]. The rationale underpinning portfolio diversification has been summed by the late Nobel Laureate James Tobin as the gains from "not to put all your eggs in one basket". The gains from asset trade by the home and a foreign country due to international portfolio diversification that results in the reduction in risks can be measured by the decrease in the volatility of returns of assets. Moreover, by international portfolio diversification of asset portfolios nations can reduce systematic risks by converting them into non-systematic risks due to the fact that international business cycles are non-synchronized. Empirical evidence reveals that in the recent past financial deregulation and increase in capital mobility has increased international portfolio diversification, but yet they remain at sub-optimal levels (Table 5).

The degree of international portfolio diversification has been measured through the correlation between the national saving rate and the investment rate. Studies for OECD countries revealed a high correlation between the above two rates implying low capital mobility and portfolio diversification according to the analysis of Feldstein and Horioka [22]. Moreover, the foreign exchange market is a key mechanism that promotes the efficient allocation of capital internationally. If the foreign exchange market is functioning efficiently the foreign exchange rate will reveal all the available information through price of foreign exchange. The efficiency of the foreign exchange market has been evaluated using three tests based on the uncovered the uncovered interest parity (UIP) condition, the risk adjusted interest parity condition and models of exchange rate forecasting. These tests fail to support that capital account liberalisation has promoted foreign exchange market efficiency, thereby casting aspersions about benefits of portfolio diversification

\footnotetext{
${ }^{1} \mathrm{Y}=\mathrm{AK}$ where $\mathrm{Y}$ : Output, $\mathrm{K}$ : Capital stock. A: constant measuring the amount of output produced per unit of capital. The change in the capital stock (DK) equals investment minus depreciation (dK) as defined below: $\mathrm{DK}=\mathrm{sY}-\mathrm{dK}$ Rearranging the above equation we obtain: $\mathrm{DY} / \mathrm{Y}=\mathrm{DK} / \mathrm{K}=\mathrm{sA}-\mathrm{d}$, If $\mathrm{sA}>\mathrm{d}$, the economy grows forever an is not subject to the law of diminishing marginal productivity that resulted in the fall of growth.
} 
Table 5. Percentage of Assets (A) and Liabilities (L) as a ratio of GDP for ACs.

\begin{tabular}{ccccc}
\hline Country & $1993(\mathrm{~A} / \mathrm{Y})$ & $2004(\mathrm{~A} / \mathrm{Y})$ & $1993(\mathrm{~L} / \mathrm{Y})$ & $2004(\mathrm{~L} / \mathrm{Y})$ \\
\hline Australia & 13 & 77 & 52 & 70 \\
Canada & 24 & 101 & 137 & 114 \\
UK & 152 & 208 & 25 & 369 \\
USA & 29 & 84 & 107 \\
\hline
\end{tabular}

Source: Lane, P.R., and Milesi-Ferretti [32] (see an updated dataset).

through capital account liberalisation, particularly in DCs according to Krugman and Obstfeld [23].

\section{The Gravity Model and the "Digital Divide”}

The Information Technology (ICT) Revolution while overcoming the 'tyranny of distance' has exacerbated the "digital divide" or the gap between information haves and information have-nots both within ACs and DCs. The measurement of the "digital divide" in terms telecommunication access lines per 100 inhabitants is an indicator of the universal service in telecommunications and a key measure of the international "digital divide" The digital divide by promoting competition and deregulation generate social benefits, spillover or positive externalities that deepen the country's skill base. It facilitates economic activity that supports electronic-commerce. The rigorous implementation of competition results in falling prices and increases innovative new products. The digital divide benefits those who have access to telecommunication infrastructure and marginalises further the ICT "have-nots". ${ }^{2}$ have increased in all regions except in Africa where growth has been negligible as shown by the study on the "digital divide" by the OECD [24]. The evidence of the benefits of liberalisation in this area is mounting in a number of DCs. Which have seen growth in wireless networks from competition.

The social benefits or positive externalities that are generated by access telecommunications infrastructure by promoting competition and creating innovative products will lead to fall in prices of telecommunication services. The "digital divide" measured in terms of internet access is much larger that when measured in terms of 100 lines per inhabitant .

The gravity model pioneered by Tinbergen [25] and Pyhonen [26] provide useful insights on how trade is

\footnotetext{
${ }^{2}$ The communications superhighway which combines the technology determinist and social constructionist view of technology and liberalisation of telecommunication markets had in 1998 the world's access lines numbered over 852 million, with $64.5 \%$ in OECD countries and in low GDP countries there were only 1.6 line per 100 inhabitants. Over the 1990s the share of OECD countries has steadily fallen partly because access lines in China has risen from 6.6million in 1990 to 87.4 million in 1998 .
}

directly related to country size as measured by GDP and inversely related to the "death of distance" been brought about the revolutionary changes in information technology. The communications superhighway concept explains how the convergence of new technologies will lay the groundwork for establishing activities such as e-commerce, telemedicine, education to germinate and address the policy issues posed by the digital divide paving the way to enhance productivity and growth.

The rationale underpinning the application of the gravity model to explain trade flows between countries can be formulated as follows:

$$
T_{i j}=\left(Y_{i} Y_{j}\right)^{\alpha} d_{i j}^{\beta}
$$

where

$T_{i j}$ : measures the trade between countries $i$ and $j$;

$Y_{i}$ : economic mass normally measured by as GDP;

$d_{i j}$ : is the distance between country $i$ and $j$;

$\alpha, \beta$ : parameters to be estimated.

Country shares and a range of other related policy variables can be included as additional explanatory variables on the right hand side of the gravity equation.

Recently, Battersby and Ewing [27] employed the gravity trade equation to explore Australia's trade openness. Their work found that the most important factor in explaining Australia's low trade to GDP ratio was the distance of the ROW and Australia's large geographic size. The application of the gravity model in the Australian context has been supplemented by a new indicator of remoteness.

The specification of the gravity model in Equation (2), has been expanded to include population and remoteness effects and common border effect through a dummy variable:

$$
T_{i j}=\left(Y_{i} Y_{j}\right)^{\alpha} d_{i j}^{\beta}\left(P_{i} P_{j}\right)^{\beta j}\left(R_{i} R_{j}\right) e^{\mu j}
$$

where

$$
\mu_{j}=\alpha+\beta 5 C_{i j}
$$

Furthermore, the Tobit respecification of the gravity model by inclusion of population hypothesizes that a country with a larger population is likely to trade less, Coe et al. [28]. The empirical validation of the gravity 
model indicates that Australia's trade performance is determined by its economic size and labor productivity.

\section{Currency Crises and Exchange Rate Misalginment}

The global economy has been ravaged by frequent currency crises before the current global financial crisis due to the Latin American debt crisis in the 1980s, the Asian currency crisis 1997-1998, followed by turmoil in Mexican crisis 1997-1990, Russia 1998 and Argentina 2001. A major issue that confronts policymakers in developing countries relate to the choice of the exchange rate regime, the exchange rate being the most important price of an open economy. Many DCs are pursuing globalization through the implementation of export-led growth strategies and avoiding an overvalued exchange rate is vital to maintain the international competitiveness of exports. A major insight from the Asian currency crisis was the focus on the bipolar case where it has been argued that developing countries to avoid recurrent currency crises have to choose one of the two corner solutions of a hard peg or a soft peg implying a floating exchange rate. However, DCs have shown a "fear of floating" because floating could increase exchange rate volatility by removing the exchange rate anchor that has tied up inflation expectations. However, empirical studies do not support the bipolar case and countries should choose the exchange rate regime taking into account its own macroeconomic fundamentals aimed at insulating the economy from external real shocks or internal monetary shocks as shown by Rogoff et al. [29].

Globalization has forced many developing countries to resolve the "open economy trilemma" by choosing independent monetary policy and capital account liberalisation thereby giving up exchange rate stability or commitment to an exchanger rate peg. Following the Asian currency crisis there has been distinct trend among emergent market economies to adopt more flexible exchange rate regimes an accumulate vast foreign exchange rate reserves to deter a possible speculative attacks of the currency peg.

Globalisation and the cross-border hyper mobility of capital have increased the vulnerability of DCs to currency crises due to sudden reversal of capital inflows. At least three generic models have been stylised to describe how speculative attacks forced a collapse of the exchange rate peg posing formidable policy challenges to DCs that have liberalized the capital account.

\section{Reshaping the International Financial Architecture}

The International Financial Architecture (IFA) refers to the three institution that were established under the Bret- ton Woods System (1946) to regulate the world monetary and banking system through the International Monetary Fund (IMF), cross-border capital flows to alleviate poverty and promote growth in developing countries through the World Bank or the International Bank for Reconstruction and Development (IBRD), to promote free trade through multilateral trade negotiations (MTN) through the General Agreement on Tariff and Trade (GATT) which was established as the World Trade Organisation (WTO) in 1995 more formal institution during the $8^{\text {th }}$ MTN round or the Uruguay Round and its scope was expanded beyond trade in manufactures to cover trade in services through the in services through the General Agreement on Trade in Services (GATs) and trade in Intellectual Property Rights (TRIPs). Furthermore, during the $9^{\text {th }}$ MTN round or the Doha round it was anticipated that the WTO will promote liberalisation o trade in agriculture by Industrial Countries reducing agricultural subsidies, import quotas on cars, steel, timber on a nonreciprocal basis.

The three institutions were the nodes in the IFA and established networks that promoted globalization policies during Wave II and Wave III when the global economy was experiencing stability and prosperity also referred to as the Great Moderation.

In mid-1997 the IFA was severely jolted by the East Asian Currency Crisis that turned overnight miracle growth economies in East Asia into debacle economies. The East Asian currency crisis highlighted the two forces of conundrum and banking institutions that were established under the BWS (1946) The International Monetary Fund (IMF) was expected promote policies that achieved internal and external balance of member nations can achieve global economic stability. The mission of the World Bank or the International Bank for Reconstruction and Development (IBRD) was to promote long-term growth and development and reduce poverty $\mathrm{n}$ member countries. The General Agreement on Tariffs and Trade (GATT) which was established formally as the World Trade Organisation (WTO) in 1995 during the $8^{\text {th }}$ MTN round or the Uruguay round extended MTN negotiations from the reduction of tariff and nontariff barriers on the reduction of trade in manufactures to cover the liberalizing trade in services through the General Agreement on Trade in Services (GATS) and in Trade Related Intellectual Property Rights (TRIPs). in the $9^{\text {th }}$ MTN or Doha round. The WTO-MTN witnessed scaling down of tariffs and NTBs.

The General Agreement for Tariff and Trade (GATT) to promote free trade in manufactured goods through multilateral trade negotiations (MTN). At the $8^{\text {th }}$ MTN the GATT was established as a formal organisation in 1995 as the World Trade Organisation (WTO), The scope of WTO was expanded to cover the trade in services 
through General Agreement in Trade in Services (GATs) and trade in patents, trademarks or trade related to intellectual property rights (TRIPs). The Doha round, the $9^{\text {th }}$ round of MTN which anticipated to the reduction of massive farm subsidies and non tariff barriers (NTBs) by industrial countries against imports from developing countries has stalled with the sudden collapse of the Wave III globalization which had delivered spectacular growth of financial innovations under free market capitalism. The global economy plunged into the worst recession since the Great Depression of the 1930s.

The Nobel Laureate Joesph Stiglitz, amongst others who worked on the coal face international monetary functioned as the chief economist of the Bank identified eight channels through which mismanagement of the process of globalization by the IFA has undermined the working of globalization. One of the most important channels is the increasing risk of the developing countries likely to face from the mismanagement of globalizations, and the highest risks can have adverse effects on growth. The lesson Stiglitz draws from his analysis is that it is not that nations should walk away from globalization but rather should implement policies mitigate these downside risks instruments. Equity finance reduces debt repayments when the economy is in a recession and unlike debt finance does not require fixed repayments regardless of the state of the economy. In reshaping the IFA facilities for increasing equity financing as opposed to debt financing of CADs and foreign debt should be promoted.

\section{Concluding Observations}

The structural malaise that has trapped DCs in a vicious circle of poverty retarding their capacity to harness the benefits of globalization has sparked off a debate between the Geography School spearheaded by Diamond [30] asserts that the vicious circle of poverty that impedes the globalization of DCs occurs because of the impediments imposed by geography resulting in debilitating tropical disease and unfavourable climate. The Institutional School associated with Acemoglu et al. [31] contends that the lack of proper institutions (enforcement of law and order, property rights) resulting in corruption retards growth and globalization of DCs. Although these rival schools offer new policy insights on why poor countries remain poor they have not yet distilled meaningful policy guidelines to tap into the virtuous cycle of globalization and growth in order to release DCs from the trap of grinding poverty and income inequality. Perhaps modern econometric analysis using appropriate instrumental variables on time-series cross-section data may offer solutions to this policy problem.

The central thesis addressed in this paper is that mainstream macroeconomic models provide insights that both support policies that promote the globalization or de- globalization of DCs depending on whether the global economy is experiencing economic prosperity or an economic downturn. Until recently the long wave (Wave III) of economic prosperity provided support for policies that promoted globalization of DCs as a way to reduce poverty and income inequality. However, the recent crisis contagion emanating from the global financial crisis triggered by the US subprime mortgage crisis has raised serious questions about the benefits of unregulated free market capitalism as the vehicle for promoting the globalization of DCs. The global financial crisis has reignited the debate on deglobalization or delinking of DCs from the international economy in order to avoid the recurrent crises originating from policy mistakes in ACs from keeping the DCs entrapped in vicious circle of poverty and income inequality.

\section{REFERENCES}

[1] K. A. O'Rourke and J. G. Williamson, "Globalization and History: The Evolution of the Nineteenth-Century Atlantic Economy," Cambridge University Press, Cambridge, 1999.

[2] D. Dollar, "Globalization, Inequality and Poverty since 1980," World Bank, Washington DC, 2001.

[3] A. Shah, "Poverty Facts and Stats," Global Issues, 2008.

[4] D. Salvatore, "Growth and Poverty in a Globalizing World," Journal of Policy Modeling, Vol. 26, No. 4, 2004, pp. 543551. doi:10.1016/j.jpolmod.2004.04.009

[5] D. R. Appleyard, A. J. Field and S. J. Cobb, "International Economics," McGraw-Hill, New York, 2006.

[6] S. Pattnaik, "The Global Financial Stability Financial Architecture Fails Again: Sub-Prime Crisis Lessons for Policymakers," Asia Pacific Economic Literature, Vol. 23, No. 1, 2009, pp. 21-47. doi:10.1111/j.1467-8411.2009.01221.x

[7] L. R. Klein, "Measurement of Shift in the World's Canter of Economic Gravity," Journal of Policy Modelling, Vol. 31, No. 4, 2009, pp. 489-492.

doi:10.1016/i.jpolmod.2009.05.005

[8] M. Gallegati, B. Greenwald, G. R. Matteo and J. E. Stiglitz, "The Asymmetric Effects of Diffusion Process: Risk Sharing and Contagion," Global Economy Journal, Vol. 8, No. 3, 2008, pp. 1-20. doi:10.2202/1524-5861.1365

[9] P. Mizen, "The Credit Crunch of 2007-2008: A Discussion of the Background, Market Reaction, and Policy Responses," Federal Reserve Bank of St. Louis Review, Vol. 90, No. 5, 2008, pp. 531-568.

[10] G. Milesi-Ferrati and A. Razin, "Current Account Sustainability Report,” Princeton University, Princeton, 1966.

[11] J. Pitchford, "Australia's Foreign Debt: Myth and Reality," Allen and Unwin, Sydney, 1990.

[12] W. M. Corden, "Economic Policy, Exchange Rates and the International System," University of Chicago Press, Chicago, 1994.

[13] N. D. Karunaratne, "The Sustainability of Australia's 
Current Account Deficits-A Reappraisal after the Global Financial Crisis," Journal of Policy Modeling, Vol. 32, No. 1, 2007, pp. 81-97. doi:10.1016/j.jpolmod.2009.10.002

[14] M. Obstfeld, J. Shambaugh and A. Taylor, "The Trilemma in History: Tradeoffs among Exchange Rates, Monetary Policies, and Capital Mobility," The Review of Economics and Statistics, Vol. 87, No. 3, 2005, pp. 423-438. doi: $10.1162 / 0034653054638300$

[15] T. W. Swan, "Economic Growth and Capital Accumulation," Economic Record, Vol. 32, No. 2, 1956, pp. 334361. doi:10.1111/j.1475-4932.1956.tb00434.x

[16] R. M. Solow, "A Contribution to the Theory of Economic Growth," Quarterly Journal of Economics, Vol. 70, No. 1, 1956, pp. 65-94. doi: $10.2307 / 1884513$

[17] P. Krugman, "The Myth of Asia's Miracle," Foreign Affairs, Vol. 73, No. 6, 1994.

[18] A. W. Young, "The Tyranny of Numbers Confronting the Statistical Realities of the East Asian Growth Experience," Quarterly Journal of Economics, Vol. 101, No. 3, 1995, pp. 641-680. doi:10.2307/2946695

[19] E. Phelps, "The Golden Rule of Accumulation: A Fable for Growth Men," American Economic Review, Vol. 51, 1996, pp. 638-643.

[20] R. J. Barro and X. Sala-I-Martin, "Convergence Across States and Regions," Brookings Papers on Economic Activity, Vol. 1991, No. 1, 1991, pp. 107-182. doi: $10.2307 / 2534639$

[21] H. Markovitz, "Portfolio Selection," Journal of Finance, Vol. 7, No. 3, 1952, pp. 77-92.

[22] M. Feldstein and C. Horioka, "Domestic Saving and International Capital Flows," Economic Journal, Vol. 90,
No. 358, 1980, pp. 314-329. doi:10.2307/2231790

[23] P. Krugman and M. Obstfeld, "International Economics: Theory and Policy," Pearson Addison-Wesley, Boston, 2009.

[24] OECD, "Understanding the Digital Divide," OECD, Paris, 2009, pp. 1-32.

[25] J. Tinbergen, "Shaping the World Economy," Twentieth Century Fund, New York, 1992.

[26] P. Pyhonen, "A Tentative Model for the Volume of Trade between Countries," Welwirtschafliches Archive, Vol. 90, 1963, pp. 93-99.

[27] B. Battersby and R. Ewing, "International Trade Performance: The Gravity of Australia's Remoteness," Treasury Working Paper, Australia, 2005, pp. 1-20.

[28] D. T. Coe, A. Subramaniam and N. T. Taminsa, "The Missing Globalization Puzzle," IMF Working Paper 02/171, The International Monetary Fund, Washington DC, 2002.

[29] K. S. Rogoff, A. M. Husain, A. Mody, R. Brooks and N. Omes, "Evolution and Performance of Exchange Rate Regimes," The International Monetary Fund, Washington DC, 2004.

[30] J. Diamond, "Guns, Germs and Steel: The Fate of Human Societies," Norton, New York, 1997.

[31] D. Acemoglu and J. Robinson, "The Colonial Origins of Comparative Development: An Empirical Interpretation," American Economic Review, Vol. 94, No. 5, 2001, pp. 1369-1321. doi:10.1257/aer.91.5.1369

[32] P. R. Lane and G. R. Miesi-Ferreti, "The External Wealth of Nations Mark II: Revised and Extended Estimates of Foreign Assets and Liabilities, 1970-2004," Journal of International Economics, Vol. 73, No. 2, 2007, pp. 223-225. doi:10.1016/j.jinteco.2007.02.003 